\title{
International Conference on Co-operation in Africa
}

A CONFERENCE to discuss means of co-ordinating the work of technical experts in Africa south of the Sahara, was held in Paris in January. It was attended by representatives of the Belgian, French, Portuguese, South African, Southern Rhodesian and United Kingdom governments, and was the latest of a series of conferences which have been held in Paris, London, Brussels, and Lisbon during the last four years. This international co-operation has resulted in the establishment of a number of joint bureaux to deal with problems such as sleeping-sickness, rinderpest, soil erosion, and the spread of plant pests and diseases.

\section{- Mass Education Bulletin'}

The first number of a periodical review of mass education was issued in December 1949 by the Mass Education Clearing House, London. The Colonial Office Mass Education (Community Development) Committee and the Colonial Department of the University of London Institute of Education have collaborated to establish a clearing house and bulletin, with the aim of gathering up the experience of all who have worked on various schemes of mass literacy, community development, and fundamental education in various parts of the world, and sharing the fruits among all who wish to do such work in future. The Bulletin will give accounts of such schemes and describe in detail the techniques used. The first number includes an editorial by the Secretary of State for the Colonies, and a survey of Mass Education in British African colonies. A similar clearing house and bulletin have been established by U.N.E.S.C.O., and the two organizations will work in close collaboration.

\section{The Bamangwato}

THE Ngwato tribe, whose chieftainship is again in dispute, are, with a population of about I 10,000, the largest of the eight tribes in the Bechuanaland Protectorate. Their Reserve, in the north-east part of the country, about 40,000 square miles in extent, contains much waterless land and the bulk of the population live in the fertile eastern strip on both sides of the Bulawayo-Mafeking railway. The tribal cpaital, Serowe, has some 25,000 inhabitants, but there are many outlying settlements of less than Ioo people each. There are about three head of cattle and three more of small stock per head of the population. The low rainfall, about Is inches a year, necessitates dispersal of cattle and fields. Adolescent boys tend the cattle at isolated posts throughout the year, while the rest of the population scatter from November to June to live near their fields of sorghum and maize. Animals and crops provide food, but cereals are imported every year from Southern Rhodesia and the Union of South Africa. Trade goods, such as clothes and blankets, also come from the Union. Some cattle are sold but the principal source of money income is migrant labour in the Union, and estimates for I 938-40 give 26 per cent. of all adult males as away from home. About 400 Europeans live in the Reserve, the men working as administrators, missionaries, railway employees, traders and blacksmiths. There are no Indians.

The Ngwato proper, descendants of the founder of the tribe, who almost all live at Serowe, make up only one-fifth of the population. The rest of the chiefdom comprises about sixteen communities of different ethnic origin, who have joined the tribe by conquest, voluntary submission, in flight from an invading enemy, or by secession from other tribes. Some, like the Ngwato themselves, belong to the Tswana (Western Sotho) cluster of Bantuspeakers. Others belong to the Northern Sotho cluster or to clusters centred on Southern Rhodesia, North-western Rhodesia and South-West Africa. There are about 10,000 Sarwa Bushmen. All have enjoyed a great deal of cultural autonomy and have their own hereditary

I Mass Education Bulletin, vol. i, No. I, Dec. 1949. Mass Education Clearing House, Colonial Department, University of London Institute of Education, Malet Street, London, W.C. I. Pp. 19. 